ISSN = 1980-993X-doi:10.4136/1980-993X
www.agro.unitau.br/ambi-agua
E-mail: ambi-agua@agro.unitau.br
Tel.: (12) 3625-4116

\title{
Occurrence of antimicrobial-resistant Enterobacteriaceae in water from different sources in a subtropical region of Argentina
} (doi:10.4136/ambi-agua.50)

\author{
Liliana Silvina Lösch ${ }^{1}$; José Mario Alonso²; Luis Antonio Merino ${ }^{3}$ \\ Instituto de Medicina Regional, Universidad Nacional del Nordeste, Chaco, Argentina \\ E-mail: ${ }^{1}$ silvinalosch1@argentina.com; ${ }^{2}$ jmalonso@gigared.com; ${ }^{3}$ lamerino@gigared.com
}

\begin{abstract}
In order to determine the occurrence of antimicrobial-resistant Enterobacteriaceae, 506 samples of drinking water, surface water, and ground water were studied in the province of Chaco, Argentina. One hundred and ninety one isolates of Enterobacteriaceae Family members were obtained. The most frequent specie was Escherichia coli and it showed the highest rate of acquired resistance, being the $\beta$-lactams the most affected antibiotics. The findings of the present work suggest that the occurrence of antimicrobial-resistant bacteria in aquatic ecosystems of Chaco may contribute to the environmental dissemination of antibiotic resistance.
\end{abstract}

Keywords: antimicrobial resistance; aquatic environments; drinking water; Enterobacteriaceae; ground water; surface water.

\section{Ocorrência de Enterobacteriaceae resistentes aos antimicrobianos nas águas de diferentes fontes em uma região subtropical de Argentina}

\section{RESUMO}

A fim de determinar a ocorrência de Enterobacteriaceae resistentes aos antimicrobianos, 506 amostras de águas de bebida, águas superficiais, e águas subterrâneas foram estudadas na província do Chaco, Argentina. Cento e noventa e um isolados de membros da família Enterobacteriaceae foram obtidos. A espécie mais freqüente foi Escherichia coli e mostrou uma taxa mais elevada de resistência adquirida, sendo os $\beta$-lactamicos os antibióticos mais afetados. Os resultados do trabalho atual sugerem que a ocorrência das bactérias resistentes aos antimicrobianos em ecossistemas aquáticos do Chaco pode contribuir para a disseminação ambiental da resistência antibiótica.

Palavras-chave: resistência antimicrobiana; ambientes aquáticos; água de bebida; Enterobacteriaceae; água subterrânea; água superficial.

\section{INTRODUCTION}

Antimicrobial resistance has an important impact on public health policies and it involves an increasing number of bacterial species and resistance mechanisms and It has been observed that the biggest increment in antibiotic-resistant bacteria occurred in those countries 
where antibiotics are extensively used for prevention or treatment of microbial infections in humans as well as in veterinary medicine (Kümmerer, 2004; Junco-Díaz et al., 2006).

Besides of the consequences for the human health, the concern of the scientific community on this topic did increase in the last years due to the geographical expansion of superficial and deep water sources contamination with resistant bacteria and with residues of antimicrobial agents or their metabolites. This situation should call the attention of scientists because antibiotics, on the contrary to other chemical compounds, exercise a direct action on bacteria and can act as persistent pollutants by its continuous emission to the different aquatic compartments (Hirsch et al., 1999; Alonso et al., 2001).

Antimicrobial surveillance programs provide important information on the development of bacterial resistance mechanisms in different geographical regions. Data concerning these mechanisms and patterns of antimicrobial resistance allows the implementation of changes in antimicrobial prescribing practices and infection control interventions (Jones and Masterton, 2001)

Most of the works about surveillance on antimicrobial resistance have been carried out in bacteria isolated from clinical samples; however, studies should also be expanded to those bacteria recovered from environmental samples in order to evaluate their role as possible reservoir of resistance genes and their capacity to transfer them to human pathogenic organisms. (Alonso et al., 2001; Harakeh et al., 2006).

Enterobacteriaceae members are broadly distributed in the environment and they are etiological agents of a great number of infectious diseases (Schreckenberger et al., 1999). Antimicrobial-resistant enterobacteria have been isolated from a variety of sources (Boon et al., 1999; Córdoba et al., 2001; Sayah et al., 2005), but up to now there is not any data about this topic in a subtropical area characterized by a great diversity of aquatic ecosystems.

The aim of the present work was to study the occurrence of antimicrobial-resistant Enterobacteriaceae in different sources of water in a subtropical region of Argentina, in order to determine their possible role as reservoir of antimicrobial resistance.

\section{MATERIALS AND METHODS}

\subsection{Study area}

The survey was performed in the province of Chaco (Northeast of Argentina), a plain region characterized by an average annual temperature of $20.5^{\circ} \mathrm{C}$, a mean annual rainfall of $1350 \mathrm{~mm}$, and with 1 million inhabitants approximately. The province has two welldifferentiated geographical regions: the western region is dry with only one river, without lakes or lagoons, and less populated than the eastern region, which is highly irrigated by rivers and present many big lagoons; the population of this last area is about 700,000 people.

\subsection{Sampling collection}

A total of 506 water samples were taken from both geographical regions, including surface waters (rivers and lagoons), ground water (perforations deeper than 6 meters), and drinking water (tankers and pipeline). Distribution of samples is shown in Table 1. 
Table 1. Locations and number of water samples (n) taken in the Province of Chaco (Northeast of Argentina).

\begin{tabular}{|c|c|c|c|c|c|c|c|c|c|c|}
\hline \multirow[b]{2}{*}{ Region } & \multirow{2}{*}{\begin{tabular}{|c|} 
Rivers \\
location
\end{tabular}} & \multicolumn{3}{|c|}{ Lagoons } & \multicolumn{2}{|c|}{ Groundwater } & \multicolumn{2}{|c|}{ Drinking water } & \multicolumn{2}{|c|}{ Total } \\
\hline & & $\mathbf{n}$ & location & $\mathbf{n}$ & location & $\mathbf{n}$ & location & $\mathbf{n}$ & locations & samples \\
\hline Western & $\begin{array}{l}\text { Bermejo } \\
\text { Malá }\end{array}$ & $\begin{array}{l}3 \\
3\end{array}$ & $\begin{array}{l}\text { Mistolar } \\
\text { Moncholo }\end{array}$ & $\begin{array}{l}3 \\
2\end{array}$ & $\begin{array}{l}\text { Avia Terai } \\
\text { Charata } \\
\text { Gancedo } \\
\text { Las Breñas } \\
\text { Machagai } \\
\text { Las Chuñas } \\
\text { Saenz Peña } \\
\text { Tres Isletas }\end{array}$ & $\begin{array}{r}4 \\
12 \\
2 \\
15 \\
4 \\
4 \\
1 \\
7 \\
3\end{array}$ & $\begin{array}{l}\text { Corzuela } \\
\text { Du Graty } \\
\text { Saenz Peña }\end{array}$ & $\begin{array}{l}2 \\
3 \\
1\end{array}$ & 15 & 67 \\
\hline Eastern & $\begin{array}{l}\text { Barranqueras } \\
\text { Negro } \\
\text { Paraná } \\
\text { Tragadero }\end{array}$ & $\begin{array}{r}2 \\
11 \\
12 \\
2\end{array}$ & $\begin{array}{l}\text { Argüello } \\
\text { Colussi } \\
\text { Los Lirios } \\
\text { Palma } \\
\text { Prosperidad } \\
\text { Tigre }\end{array}$ & $\begin{array}{c}12 \\
10 \\
27 \\
4 \\
3 \\
6\end{array}$ & $\begin{array}{l}\text { Basail } \\
\text { Escondida } \\
\text { La Leonesa } \\
\text { Las Palmas } \\
\text { Makallé } \\
\text { Pto. Tirol } \\
\text { Resistencia } \\
\text { San Martín }\end{array}$ & $\begin{array}{r}10 \\
6 \\
1 \\
1 \\
1 \\
4 \\
5 \\
2\end{array}$ & $\begin{array}{l}\text { Antequeras } \\
\text { Resistencia }\end{array}$ & $\begin{array}{l}1 \\
1\end{array}$ & 20 & 124 \\
\hline Total & 6 & 33 & 8 & 67 & 16 & 83 & 5 & 8 & 35 & 191 \\
\hline
\end{tabular}

Water samples were collected in sterile 250-ml polypropylene bottles, according to internationally recommended methodology (APHA, 1999; WHO, 2004). Samples were kept at $4^{\circ} \mathrm{C}$ until their arrival to laboratory.

\subsection{Detection and identification of Enterobacteriaceae}

The presence-absence coliform test was used as method for enrichment. Liquid media showing bacterial growth were streaked onto Eosin Methylene Blue Agar and incubated at $35^{\circ} \mathrm{C}$ during 24 hours for enterobacteria recovery (APHA, 1999; WHO, 2004). Isolates were identified by classic biochemical tests (Schreckenberger et al., 1999).

\subsection{Antimicrobial susceptibility testing}

The antimicrobial resistances were evaluated by the agar disk diffusion method (CLSI, 2005). Antibiotics selected for testing were those more frequently used in human medical practice (Famiglietti et al., 2005).

The protocol for Escherichia coli susceptibility testing included the following antimicrobial agents: ampicillin $10 \mu \mathrm{g}$, ampicillin+sulbactam $10 \mu \mathrm{g} / 10 \mu \mathrm{g}$, cephalothin $30 \mu \mathrm{g}$, cefoxitin $30 \mu \mathrm{g}$, cefotaxime $30 \mu \mathrm{g}$, ceftazidime $30 \mu \mathrm{g}$, gentamicin $10 \mu \mathrm{g}$, chloramphenicol 30 $\mu \mathrm{g}$, sulfamethoxazole-thrimethoprim $23.75 \mu \mathrm{g} / 1.25 \mu \mathrm{g}$, nalidixic acid $30 \mu \mathrm{g}$, and ciprofloxacin $5 \mu \mathrm{g}$.

Antimicrobials tested for non-E. coli isolates were: nalidixic acid $30 \mu \mathrm{g}$, chloramphenicol $30 \mu \mathrm{g}$, gentamicin $10 \mu \mathrm{g}$, sulfamethoxazole-thrimethoprim $23.75 \mu \mathrm{g} / 1.25 \mu \mathrm{g}$, ciprofloxacin 5 $\mu \mathrm{g}$, cefotaxime $30 \mu \mathrm{g}$, and ceftazidime $30 \mu \mathrm{g}$.

Escherichia coli ATCC 25922, Pseudomonas aeruginosa ATCC 27853, and Enterococcus faecalis ATCC 29212 were used as control in antimicrobial susceptibility tests. 


\subsection{Statistical analysis}

Chi-Square was applied to determine the association between different water sources and antimicrobial resistance (at 5\% significance level).

\section{RESULTS}

\subsection{Detection and identification of Enterobacteriaceae}

A total of 191 Enterobacteriaceae isolates were obtained from 506 samples analyzed. The distribution of species according to the source of water is presented in Table 2. Escherichia and Klebsiella were the most frequent genera recovered from all sources. There were not significant difference between the isolates obtained from surface water and ground water for Escherichia coli $(p=0.81)$, Klebsiella spp $(p=0.11)$, Enterobacter $\operatorname{spp}(p=0.51)$, and Citrobacter spp $(p=0.78)$. Regarding to other enterobacteria, the difference was statistically significant in favor of those isolated from ground water $(p=0.049)$, although their number was considerably smaller in comparison with the genera above mentioned.

Table 2. Number (n) and percentage (\%) of Enterobacteriaceae isolates obtained from water samples in NE Argentina, according to the source.

\begin{tabular}{|c|c|c|c|c|c|c|c|c|c|c|c|c|}
\hline \multirow{2}{*}{ Source } & \multicolumn{2}{|c|}{ E. coli } & \multicolumn{2}{|c|}{ Klebsiella spp. } & \multicolumn{2}{|c|}{ Enterobacter spp. } & \multicolumn{2}{|c|}{ Citrobacter spp. } & \multicolumn{2}{|c|}{ Others } & \multicolumn{2}{|c|}{ Total } \\
\hline & $n$ & $\%$ & $n$ & $\%$ & $n$ & $\%$ & $n$ & $\%$ & $n$ & $\%$ & $n$ & $\%$ \\
\hline Surface water & 36 & 52.9 & 35 & 62.5 & 14 & 45.2 & 14 & 56.0 & 3 & 27.3 & 102 & 53.4 \\
\hline Ground water & 30 & 44.1 & 19 & 33.9 & 14 & 45.2 & 10 & 40.0 & 8 & 72.7 & 81 & 42.4 \\
\hline Total & 68 & 100.0 & 56 & 100.0 & 31 & 100.0 & 25 & 100.0 & 11 & 100.0 & 191 & 100.0 \\
\hline
\end{tabular}

\subsection{Antimicrobial susceptibility testing}

Antibiotic resistance found in Escherichia coli isolates according to the origin of water samples is shown in Table 3.

Table 3. Antibiotic resistance of Escherichia coli isolates recovered from water samples in NE Argentina, according the origin.

\begin{tabular}{|c|c|c|c|c|}
\hline \multirow{2}{*}{ Antibiotics } & \multicolumn{3}{|c|}{ Source } & \multirow{2}{*}{$\begin{array}{c}\text { Total } \\
(n=68)\end{array}$} \\
\hline & $\begin{array}{c}\text { Surface Water } \\
(n=36)\end{array}$ & $\begin{array}{c}\text { Ground Water } \\
(n=30)\end{array}$ & $\begin{array}{c}\text { Drinking water } \\
(n=2)\end{array}$ & \\
\hline Ampicillin & $17(47.2 \%)$ & $12(40.0 \%)$ & $1(50.0 \%)$ & $30(44.1 \%)$ \\
\hline Ampicillin-sulbactam & $4(11.1 \%)$ & $0(0.0 \%)$ & $0(0.0 \%)$ & $4(5.9 \%)$ \\
\hline Cephalothin & $12(33.3 \%)$ & $6(20.0 \%)$ & $0(0.0 \%)$ & $18(26.5 \%)$ \\
\hline $\begin{array}{l}\text { Sulfamethoxazole- } \\
\text { thrimethoprim }\end{array}$ & $4(11.1 \%)$ & $0(0.0 \%)$ & $0(0.0 \%)$ & $4(5.9 \%)$ \\
\hline Chloramphenicol & $3(8.3 \%)$ & $0(0.0 \%)$ & $0(0.0 \%)$ & $3(4.4 \%)$ \\
\hline Nalidixic Acid & $3(8.3 \%)$ & $0(0.0 \%)$ & $0(0.0 \%)$ & $3(4.4 \%)$ \\
\hline
\end{tabular}

Among 30 ampicillin-resistant Escherichia coli isolates, 4 were also resistant to ampicillin/sulbactam. There were no significant differences $(p=0.5)$ between the antimicrobial resistance of the surface water isolates and the ground water isolates. 
Among the genus Klebsiella, $41 \mathrm{~K}$. pneumoniae strains, $14 \mathrm{~K}$. oxytoca and $1 \mathrm{~K}$. planticola were identified; only one $K$. pneumoniae strain from surface water was resistant to nalidixic acid and chloramphenicol.

Twenty isolates of Citrobacter sp were obtained; 5 isolates of $C$. freundii recovered from ground water were resistant to nalidixic acid but sensible to the rest of the assessed antibiotics.

In relation to the genus Enterobacter, 30 strains were recovered: 4 E. cloacae, $6 \mathrm{E}$. aerogenes, 6 E. gergoviae, and 14 Enterobacter spp. In this genus, only 1 isolate from ground water was resistant to the nalidixic acid.

In the present work was not found any extended-spectrum-ß-lactamase-producing nor ciprofloxacin-resistant strain, nevertheless, those nalidixic acid-resistant isolates must be considered as strains with decreased susceptibility for ciprofloxacin (CLSI, 2005).

\section{DISCUSSION}

High frequencies of antimicrobial resistance have been reported in bacteria recovered from environmental samples (Boon et al., 1999), and because the antibiotic resistance may be spread from resistant to formerly sensitive strains, the maintenance of antibiotic resistance in environmental isolates may act as a reservoir for antibiotic-resistance encoding genes.

Studies conducted in various countries have detected a number of antibiotics in the low microgram per liter or the nanogram per liter range in different environmental compartments (Kümmerer, 2004).

Antibiotics are present in the environment at sub-inhibitory concentrations as a consequence of hospital effluents, municipal sewage and wastewater from livestock farms or agricultural use, and its presence allows the selection of resistant strains. The presence of several antibiotic compounds in both sewage treatment plants effluents and surface waters result most likely from applications in human medicine than from veterinary uses (Hirsch et al., 1999). Added to this fact, bacteria with acquired resistance have been also found in surface water, ground water, and drinking water in different countries (McKeon et al., 1995; Schwartz et al., 2003; Córdoba et al., 2001).

Data obtained in this work about frequencies of resistant enterobacteria in water sources are in agreement with those carried out in Brazil by Lourenço et al. (2007), in United States by McKeon et al. (1995), and in South Africa by Lin et al. (2004), where E. coli was the most frequent specie followed by Citrobacter, Enterobacter and Klebsiella.

The high rate of resistance to ampicillin found in E. coli (44.1\%) in this work is superior to those previously reported in Argentina (Baldini et al., 1991) and in Australian in estuarine and river waters (Boon et al., 1999), but they are lower than those reported by Alhaj et al. (2007) in Malaysia and by Junco-Díaz et al. (2006) in Cuba. Nevertheless, our results are in agreement with those found in rivers that collect agricultural and industrial drainages in South Africa (Lin et al., 2004). These discrepancies may be due to the sources of contamination, since an important difference was found when contaminant bacteria came from domestic, wild-animals or human sewage (Sayah et al., 2005).

In this work, 26 Escherichia coli isolates presented a phenotype consistent with the presence of a plasmidic-broad-spectrum- $\beta$-lactamase (TEM-like), which hydrolyse ampicillin but is inhibited by sulbactam. This number is higher than the $4.9 \%$ found in Escherichia coli from recreational waters in Canada, which harboured the bla $a_{T E M}$ gen that codifies for a plasmidic lactamase (Hamelin et al., 2006). 
Only 4 Escherichia coli strains showed a phenotype consistent with a chromosomal hyperproduced B-lactamase which is non-inhibited by sulbactam (AmpC-like) (Risueño et al., 2002). Although some authors detected the presence of $A m p C$ genes in wastewater, surface water, and drinking water, this class $\mathrm{C}$ Ambler's $\beta$-lactamase is naturally harbored by a number of bacteria such as Escherichia coli and Shigella, but in wild state it is expressed at very low level and does not confer resistance to the aminopenicillins, except in those AmpChyperproducing strains (Livermore, 1995).

In this work there were not significant differences between the resistance levels to ampicillin among Escherichia coli isolates with those previously published by Whonet in clinical strains obtained from outpatients in Argentina (PAHO, 2005). This finding would indicate that in aquatic environments there have been a selection of resistant strains or that the strains were introduced in the water from human or animal sources.

The rate of resistance to nalidixic acid found by Goñi-Urriza et al. (2000) in Enterobacteriaceae isolated from urban effluents is close to the rate found in this work, but their findings on resistance to chloramphenicol is higher than ours.

E. coli isolates in this work presented low levels of antimicrobial resistance, which is in agreement with Lin et al. (2004), although they differ with other reports about high levels of antimicrobial-resistant bacteria isolated from rural groundwater supplies (McKeon et al., 1995) or from rivers, reservoirs, and sewage treatment facilities (Boon et al., 1999).

Even when only one ampicillin-resistant Escherichia coli strain was isolated from drinking water in our work, other authors from Germany (Schwartz et al., 2003) and from Argentina (Córdoba et al., 2001) have found many strains resistant to several antibiotics in the same kind of samples.

Some studies carried out on a large-scale distribution pilot system showed that E. coli can survive for several days in a dead-end section of the system, but does not multiply within the pipeline (Leclerc, 2003). This could be indicating that antimicrobial-resistant E. coli can reach the distribution systems by contamination of the cisterns or through leakage in the pipelines, and that they are not killed by residual chlorine concentrations. Nevertheless, the role of the environment in the emergence and spreading of antibiotic resistance bacteria, its possible pathways, and the way in which environmental bacteria contribute to the spread of resistance genes are not clearly stated so far (Schwartz et al., 2003).

Antimicrobials may have irreversible effects in the environment, even at very low concentrations, situation that is not caused by other chemical compounds. Additionally, the 5$10 \%$ of bacteria present in water is viable but non-culturable and that is why the study of antibiotic resistance allows evaluating a small fraction of the impact of antibiotics in aquatic ecosystems (Séveno et al., 2002).

There is clear evidence that if resistant bacteria enter in local waterways, their presence is associated with the risk of transferring resistant genes from harmless bacteria to pathogenic bacteria or to humans interacting with aquatic environments (Costanzo et al., 2005). Thus, water quality managers need to identify the source/s of pollution in watersheds and generally they are primary interested in discriminating if contamination is of animal or human origin, and secondarily in determining the major source of animal contamination (Harwood et al., 2000). 


\section{CONCLUSIONS}

The rates of antibiotic resistance found in Enterobacteriaceae strains recovered from environmental sources were higher than expected for wild strains. Resistance encountered can be interpreted as an indicator of the extended use of antibiotics in the region and/or the contamination of water sources with resistant bacteria originated in hospital environments. The findings of the present work are indicating that the occurrence of antimicrobial-resistant bacteria in aquatic ecosystems in the Province of Chaco may contribute significantly to environmental antibiotic resistance dissemination.

\section{ACKNOWLEDGEMENT}

This work was supported by Fundación “Alberto J. Roemmers”.

\section{REFERENCES}

ALHAJ, N.; MARIANA, N. S.; RAHA, A. R.; ISHAK, Z. Prevalence of antibiotic resistance among Escherichia coli from different sources in Malaysia. International Journal of Poultry Science, v. 6, n. 4, p. 293-297, 2007.

ALONSO, A.; SÁNCHEZ, P.; MARTÍNEZ, J. Environmental selection of antibiotic resistance genes. Environmental Microbiology, v. 3, n. 1, p. 1-9, 2001.

AMERICAN PUBLIC HEALTH ASSOCIATION - APHA. Standard methods for the examination of water and wastewater. Washington: APHA, AWWA, WEF, 1999. $1120 \mathrm{p}$.

BALDINI, M.; CABEZALÍ, C. Occurrence of antibiotic-resistance Escherichia coli isolated from environmental samples. Marine Pollution Bulletin, v. 22, n. 19, p. 500-503, 1991.

BOON, P.; CATTANACH, M. Antibiotic resistance of native and faecal bacteria isolated from rivers, reservoirs and sewage treatment facilities in Victoria, south-eastern Australia. Letter of Applied Microbiology, v. 28, n. 3, p. 164-168, 1999.

CLINICAL AND LABORATORY STANDARDS INSTITUTE - CLSI. Performance standards for antimicrobial susceptibility testing. CLSI Document M100-S15. Wayne: CLSI. 2005.

CÓRDOBA, M. A.; ROCCIA, M. L.; DE LUCA, M. M.; PEZZANI, B. C.; BASUALDO, J. A. Resistance to antibiotics in injured coliforms isolated from drinking water. Microbiology and Immunology, v. 45, n. 5, p. 383-386, 2001.

COSTANZO, S.; MURBY, J.; BATES, J. Ecosystem response to antibiotics entering the aquatic environments. Marine Pollution Bulletin, v. 51, n. 1/4, p. 218-223, 2005.

FAMIGLIETTI, A.; QUINTEROS, M.; VÁZQUEZ, M.; MARÍN, M.; NICOLA, F.; RADICE, M. et al. Consensus for antimicrobial susceptibility testing for Enterobacteriaceae. Revista Argentina de Microbiología, v. 37, n. 1, p. 57-66, 2005. 
GOÑI-URRIZA, M.; CAPDEPUY, M.; ARPIN, C.; RAYMOND, N.; CAUMETTE, P.; QUENTIN, C. Impact of an urban effluent on antibiotic resistance of riverine Enterobacteriaceae and Aeromonas spp. Applied and Environmental Microbiology, v. 66, n. 1, p. 125-132, 2000.

HAMELIN, K.; BRUANT, G.; EL-SHAARAWI, A.; HILL, S.; EDGE, T. A.; BEKAL, S. et al. A virulence and antimicrobial resistance DNA microarray detects a high frequency of virulence genes in Escherichia coli isolates from Great Lakes recreational waters. Applied and Environmental Microbiology, v. 72, n. 6, p. 4200-4206, 2006.

HARAKEH, S.; YASSINE, H.; EL-FADEL, M. Antimicrobial resistance patterns of Escherichia coli and Salmonella strains in the aquatic Lebanese environments. Environmental Pollution, v. 143, n. 2, p. 269-277, 2006.

HARWOOD, V. J.; WHITLOCK, J.; WITHINGTON, V. Classification of antibiotic resistance patterns of indicator bacteria by discriminant analysis: use in predicting the source of fecal contamination in subtropical waters. Applied and Environmental Microbiology, v. 66, n. 9, p. 3698-3704, 2000.

HIRSCH, R.; TERNES, T.; HABERER, K.; KRATZ, K. L. Occurrence of antibiotics in the aquatic environment. The Science of the Total Environment, v. 225, n. 1/2, p. 109$118,1999$.

JONES, R. N.; MASTERTON, R. Determining the value of antimicrobial surveillance programs. Diagnostic Microbiology and Infectious Disease, v. 41, n. 4, p. 171-175, 2001.

JUNCO-DÍAZ, R. A.; SUÁREZ-PITA, M. T.; WENG-ALEMÁN, Z.; CHIROLESRUBALCABA, S.; GONZÁLEZ-GONZÁLEZ, M. I.; DÍAZ-ROSA, O. E. et al. Antimicrobial susceptibility in bacteria of environmental origin. Higiene $\mathbf{y}$ Sanidad Ambiental, v. 6, p. 150-159, 2006.

KÜMMERER, K. Resistance in the environment. Journal of Antimicrobial Chemotherapy, v. 54, n. 2, p. 311-320, 2004.

LECLERC, H. Relationships between common water bacteria and pathogens in drinking-water. Heterotrophic plate counts and drinking-water safety. London: IWA Publishing, 2003. 118 p.

LIN, J.; BIYELA, P.T.; PUCKREE, T. Antibiotic resistance profiles of environmental isolates from Mhlathuze River, KwaZulu-Natal (RSA). Water SA, v. 30, n. 1, p. 23-28, 2004.

LIVERMORE, D.M. B-lactamases in laboratory and clinical resistance. Clinical Microbiology Reviews, v. 8, n. 4, p. 557-584, 1995.

LOURENÇO, N. G. G. S.; TAKAHASHI, C. K.; LOPES, T. F.; LOPES, C. A. M. Environmental parameters and antimicrobial susceptibility of Enterobacteriaceae isolated from estuarine waters of São Vicente, São Paulo State, Brazil. Journal of Venomous Animals Toxins including Tropical Diseases, v. 13, n. 2, p. 472-478, 2007. 
MCKEON, D. M.; CALABRESE, J. P.; BISSONNETTE, G. K. Antibiotic resistant Gramnegative bacteria in rural groundwater supplies. Water Research, v. 29, n. 8, p. 19021908, 1995.

PAN AMERICAN HEALTH ORGANIZATION - PAHO. Annual report of the monitoring/surveillance network for resistance to antibiotics, 2004, Brazil (Spanish). Washington: PAHO/WHO, 2005. 115 p.

RISUEÑO, F.; CARDONA, E.; OTERO, B. Interpretive reading of the antibiogram of enterobacterias. Enfermedades Infecciosas \& Microbiología Clínica, v. 20, n. 5, p. 225-234, 2002.

SAYAH, R. S.; KANEENE, J. B.; JOHNSON, Y.; MILLER, R. A. Patterns of antimicrobial resistance observed in Escherichia coli isolates obtained from domestic- and wildanimal fecal samples, human septage, and surface water. Applied and Environmental Microbiology, v. 71, n. 3, p. 1394-1404, 2005.

SCHRECKENBERGER, P.C.; JANDA, J. M.; WONG, J. D.; BARON E. J. Algorithms for identification of aerobic gramnegative bacteria. In: Manual of Clinical Microbiology. Washington: ASM Press, 1999. p. 438-441.

SCHWARTZ, T.; KOHNEN, W.; JANSEN, B.; OBST, U. Detection of antibiotic-resistant bacteria and their resistance genes in wastewater, surface water, and drinking water biofilms. FEMS Microbiology Ecology, v. 43, n. 3, p. 325-335, 2003.

SÉVENO, N. A.; KALLIFIDAS, D.; SMALLA, K.; VAN ELSAS, J. D.; COLLARD, J. M.; KARAGOUNI, A. D. et al. Occurrence and reservoirs of antibiotic resistance genes in the environment. Reviews in Medical Microbiology, v. 13, n. 1, p. 15-27, 2002.

WORLD HEALTH ORGANIZATION - WHO. Guidelines for drinking-water quality. 3. ed. Geneva: WHO, 2004. 595 p. 